\title{
PENGETAHUAN PERPAJAKAN, SOSIALISASI PERPAJAKAN, DAN PELAYANAN FISKUS TERHADAP KEPATUHAN WAJIB PAJAK
}

\author{
R. A. Meiska Lianty \\ 1meiskalianty@students.telkomuniversity.ac.id \\ Dini Wahjoe Hapsari \\ Kurnia \\ Fakultas Ekonomi dan Bisnis, Universitas Telkom
}

\begin{abstract}
This study aims to discover how the effect of the tax knowledge, tax socialization, and tax authorities service, either simultaneously or partially, on the taxpayers compliance in KPP Pratama Bandung Bojonagara. The research samples are the whole number of the non-employee individual taxpayers in the amount of 100 people. The sampling technique is convenience sampling and the analysis method is using multiple linear regression. Simultaneously, the tax knowledge, the tax socialization, and the tax authorities service significantly affect the taxpayers compliance in KPP Pratama Bandung Bojonagara. Partially, the result shows that both the tax knowledge and the tax authorities service significantly have positive effect and are directly proportional on the taxpayers compliance. On the other hand, the tax socialization has no significant effect on the taxpayers compliance in KPP Pratama Bandung Bojonagara.
\end{abstract}

Keywords : tax knowledge, tax socialization, tax authorities service, taxpayers compliance, non-employee individual taxpayers

\begin{abstract}
Abstrak
Penelitian ini bertujuan untuk mengetahui bagaimana pengaruh pengetahuan perpajakan, sosialisasi perpajakan, dan pelayanan fiskus baik secara simultan maupun parsial terhadap kepatuhan Wajib Pajak OP (Non Karyawan) di KPP Pratama Bandung Bojonagara. Sampel penelitian ini adalah Wajib Pajak OP (Non Karyawan) yang berjumlah 100 orang. Teknik sampel yang digunakan adalah convenience sampling dan metode analisis menggunakan regresi linier berganda. Hasil penelitian menunjukkan bahwa secara simultan pengetahuan perpajakan, sosialisasi perpajakan, dan pelayanan fiskus berpegaruh signifikan terhadap kepatuhan Wajib Pajak OP (Non Karyawan) di KPP Pratama Bandung Bojonagara. Secara parsial, pengetahuan perpajakan dan pelayanan fiskus berpengaruh signifikan dengan arah yang positif terhadap kepatuhan Wajib Pajak OP (Non Karyawan) sedangkan sosialisasi perpajakan tidak berpengaruh signifikan terhadap kepatuhan Wajib Pajak OP (Non Karyawan) di KPP Pratama Bandung Bojonagara.
\end{abstract}

Kata Kunci : pengetahuan perpajakan, sosialisasi perpajakan, pelayanan fiskus, kepatuhan wajib pajak, wajib pajak non karyawan 


\section{PENDAHULUAN}

Suatu negara dapat melaksanakan pembangunan nasional apabila terdapat dana yang tersedia untuk membiayai pembangunan tersebut. Sumber dana atau sumber penerimaan suatu negara pada dasarnya dapat dibedakan menjadi penerimaan yang bersumber dari sektor internal dan eksternal. Salah satu sumber penerimaan negara yang berasal dari sektor internal adalah pajak. Menurut Undang-Undang Nomor 16 Tahun 2009 tentang perubahan ke-empat atas UndangUndang Nomor 6 Tahun 1983 Tentang Ketentuan Umum dan Tata Cara Perpajakan pada Pasal 1 Angka 1, pajak adalah kontribusi wajib kepada negara yang terutang oleh orang pribadi atau badan yang bersifat memaksa berdasarkan Undang-Undang dengan tidak mendapatkan imbalan secara langsung dan digunakan untuk keperluan negara bagi sebesar-besarnya kemakmuran rakyat. Pajak memiliki peranan yang sangat penting sebagai sumber utama penerimaan negara, oleh karena itu pelaksanaan perpajakan sangat diatur guna mempertahankan penerimaan negara.

Salah satu indikator yang digunakan pemerintah untuk mengukur keberhasilan dalam penerimaan negara yang bersumber dari pajak adalah tax ratio. Simanjuntak dan Mukhlis (2012) menyatakan bahwa semakin besar tax ratio menunjukkan atau mengisyaratkan bahwa semakin besar pula porsi penerimaan pajak dalam APBN. Menteri Keuangan Bambang P.S. Brodjonegoro menilai, rasio penerimaan perpajakan (tax ratio) Indonesia yang saat ini berada di kisaran 11\% (persen) masih berada di bawah standar negara-negara ASEAN dan Organization on Economic Cooperation and Development (http://www.kemenkeu.go.id/Berita/ menkeu-tax-ratio-indonesia-di-bawah-standar, 2016). Tax ratio di Indonesia yang hanya berkisar sebesar $11 \%$ dan masih berada di bawah standar negara-negara ASEAN dan Organization on Economic Cooperation and Development menunjukkan bahwa penerimaan pajak dalam APBN masih tergolong rendah. Dalam lima tahun terakhir berdasarkan laporan keuangan pemerintah pusat, diketahui bahwa penerimaan pajak tidak berhasil mencapai target yang telah ditetapkan dalam APBN dan persentase realisasi penerimaan terhadap anggarannya pun terus menurun setiap tahunnya.

Salah satu cara yang dapat dilakukan untuk meningkatkan penerimaan pajak adalah dengan meningkatkan rasio kepatuhan pajak atau tax compliance ratio. Namun faktanya, di Indonesia rasio kepatuhan atau tingkat kepatuhan Wajib Pajak dalam menjalankan kewajiban perpajakannya masih rendah. Hal tersebut dapat dilihat berdasarkan jumlah Wajib Pajak (WP) yang terdaftar dalam sistem administrasi Direktorat Jenderal Pajak (DJP) mencapai 30.044.103 WP, hal ini cukup memprihatinkan mengingat menurut data Badan Pusat Statistik (BPS), hingga tahun 2013, jumlah penduduk Indonesia yang bekerja mencapai 93,72 juta orang. Artinya baru sekitar $29,4 \%$ dari total jumlah Orang Pribadi Pekerja dan berpenghasilan di Indonesia yang mendaftarkan diri atau terdaftar sebagai WP. Kemudian dari jumlah 30.044.103 WP yang terdaftar, didapatkan sebanyak 18.159.840 WP Wajib SPT yang Wajib menyampaikan SPT Tahunan PPh dan dari jumlah tersebut baru 10.945.567 WP atau 60,27\% dari jumlah total WP Wajib SPT yang menyampaikan SPT Tahunan (http://www.pajak.go.id/content/article/refleksi-tingkatkepatuhan-wajib-pajak, 2016).

Dalam penelitian ini, peneliti akan menjadikan KPP Pratama Bandung Bojonagara sebagai objek penelitian dan Wajib Pajak Orang Pribadi (Non Karyawan) yang melakukan kegiatan usaha atau pekerjaan bebas sebagai responden untuk menjawab kuesioner penelitian. Di KPP Pratama Bandung Bojonagara terlihat bahwa setiap tahunnya jumlah realisasi SPT jauh lebih rendah dibandingkan dengan jumlah WP OP (Non Karyawan) Wajib SPT. Hal tersebut dapat dilihat pada tabel berikut:

Tabel 1. Rasio Kepatuhan Wajib Pajak OP (Non Karyawan) KPP Pratama Bandung Bojonagara

\begin{tabular}{ccccc}
\hline No & Tahun & $\begin{array}{c}\text { Jumlah Wajib } \\
\text { Pajak OP(Non } \\
\text { Karyawan) } \\
\text { yang Terdaftar } \\
\text { Wajib SPT }\end{array}$ & $\begin{array}{c}\text { Realisasi } \\
\text { SPT Wajib } \\
\text { Pajak OP } \\
\text { (Non } \\
\text { Karyawan) }\end{array}$ & $\begin{array}{c}\text { Rasio } \\
\text { Kepatuhan } \\
\text { Wajib Pajak OP } \\
\text { (Non } \\
\text { Karyawan) }\end{array}$ \\
\hline 1 & 2012 & 16.677 & 5.267 & $32 \%$ \\
2 & 2013 & 12.126 & 5.470 & $45 \%$ \\
3 & 2014 & 9.826 & 5.413 & $55 \%$ \\
4 & 2015 & 8.073 & 5.667 & $70 \%$ \\
\hline
\end{tabular}

Sumber: KPP Pratama Bandung Bojonagara (2016).

Berdasarkan Tabel 1 dapat dilihat bahwa kepatuhan Wajib Pajak Orang Pribadi (Non Karyawan) di KPP Pratama Bandung Bojonagara hingga tahun 2015 baru mencapai $70 \%$, dimana dari jumlah Wajib Pajak Orang Pribadi (Non Karyawan) yang terdaftar Wajib SPT sebanyak 8.073 Wajib Pajak hanya sebanyak 5.667 Wajib Pajak yang melaporkan atau menyampaikan SPT. Hal tersebut menunjukkan bahwa masih ada Wajib Pajak Orang Pribadi (Non Karyawan) di KPP Pratama Bandung Bojonagara yang belum patuh dalam melaksanakan kewajiban perpajakannya.

Safri Nurmantu dalam Rahayu (2010:138) mengatakan bahwa kepatuhan perpajakan/kepatuhan Wajib Pajak merupakan suatu keadaan dimana Wajib Pajak memenuhi seluruh kewajiban perpajakan dan melaksanakan hak perpajakannya. Kepatuhan Wajib Pajak dapat dipengaruhi oleh beberapa faktor. Salah satu faktor yang dapat mempengaruhinya adalah pengetahuan perpajakan. Kurangnya pengetahuan perpajakan yang dimiliki Wajib Pajak dapat menjadi kendala dalam pelaksanaan kewajibaan perpajakan (Zuhdi, et al, 2015). Menurut Kepala Bidang Penyuluhan, Pelayanan \& Humas Kanwil Direktorat Jenderal Pajak Wajib Pajak 
Besar Hatipah Haroen Al Rasjid, pemahaman dan kesadaran masyarakat Indonesia untuk patuh membayar pajak masih minim. Hal ini karena pengetahuan mengenai pajak yang diperoleh masyarakat belum optimal (http:// www.pikiran-rakyat.com/ekonomi/2013/12/18/262926/ kesadaran-masyarakat-bayar-pajak-minim, diakses 03/03/2017). Dengan memiliki pengetahuan perpajakan yang baik Wajib Pajak akan mengetahui dan memahami seluruh ketentuan terkait dengan kewajiban perpajakan yang berlaku maka Wajib Pajak akan dengan mudah melaksanakan kewajiban perpajakannya dan pada akhirnya akan menignkatkan kepatuhan Wajib Pajak itu sendiri (Zuhdi, et al 2015). Didukung oleh penelitian yang dilakukan Zuhdi, et al (2015) yang menyatakan bahwa pengetahuan perpajakan berpengaruh terhadap kepatuhan Wajib Pajak dan penelitian yang dilakukan oleh Murti, et al (2014) yang menyatakan bahwa pengetahuan perpajakan berpengaruh secara signifikan terhadap kepatuhan Wajib Pajak Orang Pribadi. Didukung pula oleh penelitian yang dilakukan Oladipupo dan Obazee (2016), Saad (2014), dan Palil, et al (2013). Tetapi tidak dengan penelitian yang dilakukan oleh Pratiwi (2012) yang menyatakan bahwa pengetahuan perpajakan tidak berpengaruh terhadap kepatuhan Wajib Pajak, penelitian yang dilakukan oleh Andinata (2015) juga menyatakan bahwa pengetahuan serta pemahaman tentang peraturan perpajakan tidak memiliki pengaruh yang signifikan terhadap kepatuhan Wajib Pajak, begitu pula dengan penelitian yang dilakukan oleh Andreas dan Savitri (2015).

Faktor kedua yang dapat mempengaruhi kepatuhan Wajib Pajak adalah sosialisasi perpajakan. Direktorat Jendral Pajak Kementerian Keuangan hingga saat ini masih terus melakukan sosialisasi mengenai arti penting membayar pajak. Direktur Jenderal Pajak, Sigit Priadi Pramudito menjelaskan, masih belum maksimalnya penerimaan pajak oleh pemerintah bukan semata-mata kesalahan masyarakat. Sigit mengaku pihaknya juga kurang bekerja maksimal. Sigit mengungkapkan bahwa Pengetahuan Wajib Pajak (WP) yang masih minim disebabkan oleh kurangnya sosialisasi dari Direktorat Jenderal Pajak. DJP mengakui kesalahannya tersebut. Untuk memperbaiki kesalahan tersebut, dikatakan Sigit, pada tahun ini dirinya akan bekerja lebih maksimal dimana pemerintah juga telah mencanangkan/di tahun 2015 sebagai tahun pembinaan untuk seluruh wajib pajak (http://bisnis.liputan6.com/read/2338480/penerimaanpajak-masih-rendah-dirjen-pajak-mengaku-salah, diakses 24/01/17). Dari uraian tersebut dapat dikatakan bahwa ketidakpatuhan masyarakat atau Wajib Pajak dalam membayar pajak yang menyebabkan belum maksimalnya penerimaan pajak bukan semata-mata karena kesalahan mereka, tetapi ketidakpatuhan masyarakat atau Wajib Pajak juga disebabkan karena kurangnya sosialisasi perpajakan dari Direktorat Jenderal Pajak. Sosialisasi perpajakan memiliki peranan penting dalam meningkatkan kepatuhan Wajib Pajak, karena dengan adanya sosialisasi perpajakan baik secara langsung maupun tidak langsung, Wajib Pajak akan memperoleh pemahaman serta informasi mengenai ketentuan perpajakan sehingga membuat Wajib Pajak mengerti atau paham dan sadar atas kewajibannya untuk menyetor dan melaporkan kewajiban perpajakannya secara rutin (Yuliasari, et al 2015), dengan sosialisasi ini juga masyarakat atau Wajib Pajak menjadi paham tentang manfaat membayar pajak serta sanksi jika tidak membayar pajak (Winerungan, 2013), yang pada akhirnya hal tersebut akan membuat Wajib Pajak menjadi patuh dalam melaksanakan kewajiban perpajakannya. Didukung oleh penelitian yang dilakukan oleh Dharma dan Suardana (2014) yang menyatakan bahwa sosialisasi perpajakan berpengaruh signifikan terhadap kepatuhan Wajib Pajak dalam membayar pajak. Namun, tidak dengan penelitian yang dilakukan oleh Yuliasari, et al (2015) yang menyatakan bahwa sosialisasi perpajakan tidak berpengaruh secara signifikan terhadap kepatuhan Wajib Pajak Orang Pribadi dan penelitian yang dilakukan oleh Winerungan (2013) yang menyatakan bahwa sosialisasi perpajakan tidak berpengaruh terhadap kepatuhan Wajib Pajak Orang Pribadi, begitu pula dengan penelitian yang dilakukan oleh Savitri dan Musfialdy (2016) serta Andreas dan Savitri (2015).

Faktor ketiga yang dapat mempengaruhi kepatuhan Wajib Pajak adalah pelayanan fiksus. Pelayanan yang diberikan oleh fiskus selama proses perpajakan berkaitan dengan sikap Wajib Pajak dalam melaksanakan kewajiban perpajakannya (Murti, et al 2014). Berdasarkan berbagai penelitian yang telah dilakukan, dikatakan bahwa masalah kepatuhan dapat dilihat dari beberapa hal diantaranya struktur organisasi (organizational structure), tenaga kerja (employees), dan etika (code of conduct) (Andreoni et al. 1998). Ketiga hal tersebut lebih ditekankan pada masalah internal di lingkungan kantor pajak. Apabila struktur organisasinya memungkinkan kantor pajak untuk melayani wajib pajak dengan profesional, maka wajib pajak akan cenderung mematuhi berbagai aturan (http://www.pajak.go.id/content/strategi-meningkatkankepatuhan-wajib-pajak, diakses 18/12/16). Wajib Pajak secara konsisten akan meningkatkan kepatuhan bila terdapat pelayanan yang baik oleh aparat perpajakan (Yuliasari, et al 2015). Dengan kata lain, dengan adanya pelayanan yang baik dari petugas pajak atau fiskus maka akan membuat Wajib Pajak merasa senang dan nyaman dalam menjalankan kewajiban perpajakannya sehingga akan membuat Wajib Pajak konsisten atau cenderung untuk patuh dalam melaksanakan kewajiban perpajakannya sesuai dengan ketentaun yang berlaku. Didukung oleh penelitian yang dilakukan oleh Yuliasari, et al (2015) yang menyatakan bahwa pelayanan fiskus berpengaruh secara signifikan terhadap kepatuhan Wajib Pajak. Begitu pula dengan penelitian yang dilakukan oleh Murti, et al (2014) yang menyatakan bahwa pelayanan fiskus berpengaruh secara signifikan terhadap 
kepatuhan Wajib Pajak Orang Pribadi. Penelitian yang dilakukan oleh Dharma dan Suardana (2014) juga menyatakan bahwa kualitas pelayanan berpengaruh secara signifikan terhadap kepatuhan Wajib Pajak dalam membayar pajak. Didukung pula oleh penelitian Andreas dan Savitri (2015). Namun, lain halnya dengan penelitian yang dilakukan oleh Winerungan (2013) yang menyatakan pelayanan fiskus tidak berpengaruh terhadap kepatuhan Wajib Pajak Orang Pribadi dan penelitian yang dilakukan oleh Andinata (2015) yang menyatakan bahwa kualitas pelayanan fiskus tidak memiliki pengaruh yang signifikan terhadap kepatuhan Wajib Pajak.

Berdasarkan uraian tersebut dan karena adanya inkonsistensi hasil pada penelitian sebelumnya yang telah dilakukan oleh Pratiwi (2012), Winerungan (2013), Andinata (2015), Yuliasari, et al (2015), Andreas dan Savitri (2015), serta Savitri dan Musfialdy (2016), peneliti tertarik untuk melakukan penelitian dengan judul "Pengaruh Pengetahuan Perpajakan, Sosialisasi Perpajakan, dan Pelayanan Fiskus Terhadap Kepatuhan Wajib Pajak (Studi Pada Wajib Pajak Orang Pribadi (Non Karyawan) Yang Melakukan Kegiatan Usaha atau Pekerjaan Bebas di KPP Pratama Bandung Bojonagara Tahun 2015)". Tujuan dari penelitian ini adalah untuk mengetahui bagaimana pengetahuan perpajakan WP OP (Non karyawan), sosialisasi perpajakan, pelayanan fiskus, dan kepatuhan WP OP (Non Karyawan) di KPP Pratama Bandung Bojonagara serta untuk mengetahui bagaimana pengaruh secara simultan dan parsial pengetahuan perpajakan, sosialisasi perpajakan, dan pelayanan fiskus terhadap kepatuhan Wajib Pajak Orang Pribadi (Non Karyawan) di KPP Pratama Bandung Bojonagara Tahun 2015.

Menurut Mardiasmo (2016:7), pengetahuan perpajakan dapat diartikan sebagai segala sesuatu yang diketahui dan dipahami sehubungan dengan hukum pajak, baik hukum pajak materiil maupun hukum pajak formil. Dengan Wajib Pajak mengetahui dan memahami seluruh ketentuan terkait dengan kewajiban perpajakan yang berlaku maka Wajib Pajak akan dengan mudah melaksanakan kewajiban perpajakannya (Zuhdi, et al 2015). Menurut Rahayu (2010:29), dengan tingkat pengetahuan perpajakan yang baik dan memadai yang dimiliki oleh masyarakat khususnya Wajib Pajak, maka akan mudah bagi Wajib Pajak untuk patuh pada peraturan perpajakan yang akhirnya akan meningkatkan kepatuhan dari Wajib Pajak itu sendiri. Didukung oleh penelitian yang dilakukan Zuhdi, et al (2015) yang menyatakan bahwa pengetahuan perpajakan berpengaruh terhadap kepatuhan Wajib Pajak dan penelitian yang dilakukan oleh Murti, et al (2014) yang menyatakan bahwa pengetahuan perpajakan berpengaruh secara signifikan terhadap kepatuhan Wajib Pajak Orang Pribadi. Didukung pula oleh penelitian yang dilakukan Oladipupo dan Obazee (2016), Saad
(2014), dan Palil, et al (2013). Hipotesis yang diajukan, Pengetahuan Perpajakan berpengaruh positif terhadap Kepatuhan Wajib Pajak Orang Pribadi (Non Karyawan) di KPP Pratama Bandung Bojonagara.

Berdasarkan Surat Edaran Direktur Jenderal Pajak Nomor: SE-98/PJ/2011 dikatakan bahwa sosialisasi perpajakan merupakan suatu upaya dan proses memberikan informasi perpajakan untuk menghasilkan perubahan pengetahuan, keterampilan, dan sikap masyarakat, dunia usaha, aparat, serta lembaga pemerintah maupun non pemerintah agar terdorong untuk paham, sadar, peduli dan berkontribusi dalam melaksanakan kewajiban perpajakan. Sosialisasi perpajakan memiliki peranan penting dalam meningkatkan kepatuhan Wajib Pajak, karena dengan adanya sosialisasi perpajakan baik secara langsung maupun tidak langsung, Wajib Pajak akan memperoleh pemahaman serta informasi mengenai ketentuan perpajakan sehingga membuat Wajib Pajak mengerti atau paham dan sadar atas kewajibannya untuk menyetor dan melaporkan kewajiban perpajakannya secara rutin (Yuliasari, et al 2015), dengan sosialisasi ini juga masyarakat atau Wajib Pajak menjadi paham tentang manfaat membayar pajak serta sanksi jika tidak membayar pajak (Winerungan, 2013) yang pada akhirnya hal tersebut akan membuat Wajib Pajak menjadi patuh dalam melaksanakan kewajiban perpajakannya. Menurut Rahayu (2010:141), dengan DJP melakukan sosialisasi perpajakan secara intensif dan kontinyu maka akan meningkatkan pemahaman Wajib Pajak tentang kewajibannya membayar pajak. Sehingga akan membuat Wajib Pajak patuh dalam melaksanakan kewajiban perpajakannya. Didukung oleh penelitian yang dilakukan oleh Dharma dan Suardana (2014) yang menyatakan bahwa sosialisasi perpajakan berpengaruh signifikan terhadap kepatuhan Wajib Pajak dalam membayar pajak. Hipotesis yang diajukan, Sosialisasi Perpajakan berpengaruh positif terhadap Kepatuhan Wajib Pajak Orang Pribadi (Non Karyawan) di KPP Pratama Bandung Bojonagara.

Berdasarkan Surat Edaran Direktur Jenderal Pajak Nomor SE-84/PJ/2011 dikatakan bahwa pelayanan fiskus/pelayanan prima merupakan pelayanan yang berkualitas dan bermutu yang diberikan oleh fiskus kepada Wajib Pajak untuk memenuhi kebutuhan dan harapan Wajib Pajak dan bertujuan untuk mencapai tingkat kepuasan Wajib Pajak yang tinggi atas pelayanan perpajakan. Wajib Pajak secara konsisten akan meningkatkan kepatuhan bila terdapat pelayanan yang baik oleh aparat perpajakan (Yuliasari, et al 2015). Sehingga dapat dikatakan bahwa semakin baik pelayanan yang diberikan oleh fiskus kepada Wajib Pajak dapat membuat Wajib Pajak merasa senang dan nyaman dalam melaksanakan kewajiban perpajakannya, dalam kondisi Wajib Pajak merasa senang, nyaman, dan puas atas pelayanan yang diberikan 
akan membuat Wajib Pajak konsisten atau cenderung untuk melaksanakan kewajiban perpajakannya sesuai dengan ketentuan yang berlaku yang pada akhirnya dapat meningkatkan kepatuhan dari Wajib Pajak itu sendiri. Menurut Rahayu (2010:28) dengan adanya pelayanan bersifat prima atau pelayanan yang baik yang diberikan oleh fiskus kepada Wajib Pajak dapat mencapai tingkat kepatuhan Wajib Pajak yang tinggi, dalam kondisi Wajib Pajak merasa puas atas pelayanan yang diberikan oleh fiskus maka Wajib Pajak cenderung akan melaksanakan kewajiban perpajakannya sesuai dengan ketentuan yang berlaku. Didukung oleh penelitian yang dilakukan oleh Yuliasari, et al (2015) yang menyatakan bahwa pelayanan fiskus berpengaruh secara signifikan terhadap kepatuhan Wajib Pajak. Begitu pula dengan penelitian yang dilakukan oleh Murti, et al (2014) yang menyatakan bahwa pelayanan fiskus berpengaruh secara signifikan terhadap kepatuhan Wajib Pajak Orang Pribadi. Penelitian yang dilakukan oleh Dharma dan Suardana (2014) juga menyatakan bahwa kualitas pelayanan berpengaruh secara signifikan terhadap kepatuhan Wajib Pajak dalam membayar pajak. Didukung pula oleh penelitian Andreas dan Savitri (2015). Hipotesis yang diajukan, Pelayanan Fiskus berpengaruh positif terhadap Kepatuhan Wajib Pajak Orang Pribadi (Non Karyawan) di KPP Pratama Bandung Bojonagara.

\section{METODE}

Operasionalisasi variabel penelitian ditunjukkan pada Tabel 1.

Tabel 1. Operasionalisasi Variabel

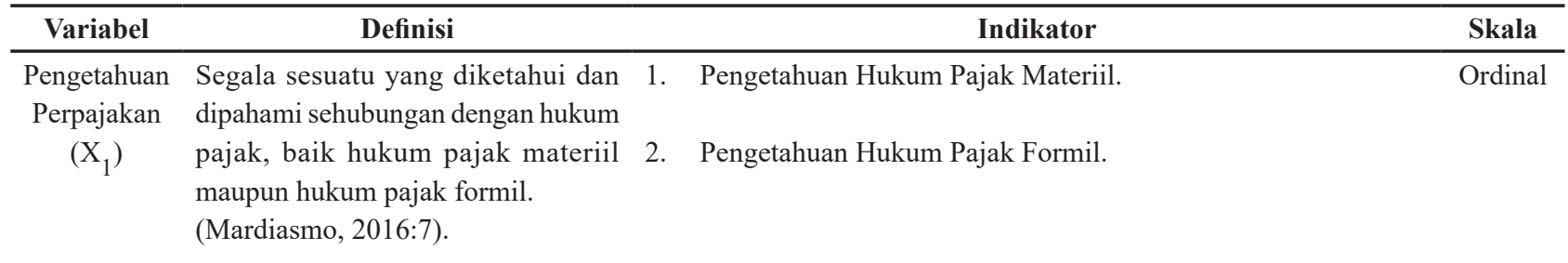

Sosialisasi Suatu upaya dan proses memberikan 1. Penyuluhan Langsung.

Ordinal

Perpajakan informasi perpajakan untuk

$\left(\mathrm{X}_{2}\right) \quad$ menghasilkan perubahan pengetahuan, 2. Penyuluhan Tidak Langsung.

keterampilan, dan sikap masyarakat, dunia usaha, aparat, serta lembaga pemerintah maupun non pemerintah agar terdorong untuk paham, sadar, peduli dan berkontribusi dalam melaksanakan kewajiban perpajakan. (Surat Edaran Direktur Jenderal Pajak Nomor: SE-98/PJ/2011)

\begin{tabular}{|c|c|c|c|}
\hline $\begin{array}{l}\text { Pelayanan } \\
\text { Fiskus }\left(\mathrm{X}_{3}\right)\end{array}$ & $\begin{array}{l}\text { Pelayanan yang berkualitas dan } \\
\text { bermutu yang diberikan oleh fiskus } \\
\text { kepada Wajib Pajak untuk memenuhi } \\
\text { kebutuhan dan harapan Wajib Pajak } \\
\text { dan bertujuan untuk mencapai tingkat } \\
\text { kepuasan Wajib Pajak yang tinggi atas } \\
\text { pelayanan perpajakan. } \\
\text { (Surat Edaran Direktur Jenderal } \\
\text { Pajak Nomor SE-84/PJ/2011 tentang } \\
\text { Pelayanan Prima) }\end{array}$ & 1. & $\begin{array}{l}\text { Waktu pelayanan di TPT (KPP) adalah pukul } 08.00 \mathrm{~s} / \mathrm{d} 16.00 \\
\text { waktu setempat; } \\
\text { Wajib Pajak memperoleh pelayanan sebagai berikut: } \\
\text { a. Pada area umum, WP boleh dengan bebas keluar masuk } \\
\text { untuk mendapatkan pelayanan perpajakan yang baik sesuai } \\
\text { dengan standar mutu pelayanan dan WP yang memerlukan } \\
\text { pelayanan pada restricted area harus memenuhi syarat-syarat } \\
\text { tertentu; } \\
\text { b. Pegawai menjaga sopan santun dan perilaku, ramah } \\
\text { (memberikan sapa, senyum, dan salam) kepada WP, tanggap, } \\
\text { cermat dan cepat, serta tidak mempersulit pelayanan; } \\
\text { c. Apabila ada panggilan penting dan terpaksa harus } \\
\text { meninggalkan WP, petugas memohon maaf kepada WP; } \\
\text { d. Petugas konseling (helpdesk) siaga melayani pertanyaan WP; } \\
\text { e. AR yang pada saat bersamaan menerima tamu yang } \\
\text { merupakan WP tanggungjawa-bnya, maka WP lain ditangani } \\
\text { oleh AR/petugas lain; }\end{array}$ \\
\hline
\end{tabular}


f. Petugas pada KPP memiliki kemampuan bahasa Inggris untuk melayani WP Orang Asing;

g. Dalam merespon permasalahan dan memberikan informasi petugas memberikan informasi atau penjelasan secara lengkap dan jelas sehingga WP dapat mengerti dengan baik;

h. Terdapat petugas keamanan yang menyambut, menanyakan keperluan dan mempersilahkan dengan sopan tamu atau WP untuk mengambil nomor antrian;

i. Apabila antrian cukup panjang dan waktu menunggu lebih lama maka petugas harus memberikan penjelasan dengan baik, sopan dan tetap bersikap ramah;

j. Apabila terjadi aliran listrik padam atau sistem sedang rusak atau terganggu yang mengakibatkan petugas tidak dapat melayani dengan baik, sehingga WP menjadi tidak sabar/ marah, maka yang harus diperhatikan adalah petugas tetap bersikap ramah dan meminta maaf atas situasi tersebut;

k. Bila Petugas terpaksa tidak dapat menerima laporan/surat yang disampaikan WP, misalnya karena kurang lengkap, maka petugas harus menjelaskannya secara jelas dan ramah sampai WP memahami dengan baik.

\begin{tabular}{|c|c|c|c|}
\hline $\begin{array}{l}\text { Kepatuhan } \\
\text { Wajib Pajak } \\
\text { (Y) }\end{array}$ & $\begin{array}{l}\text { Suatu keadaan di mana Wajib } \\
\text { Pajak memenuhi seluruh kewajiban } \\
\text { perpajakan dan melaksanakan hak } \\
\text { perpajakannya. } \\
\text { (Safri Nurmantu dalam Rahayu, } \\
\text { 2010:138) }\end{array}$ & 1. Kepatuhan Formal. & Ordinal \\
\hline
\end{tabular}

Populasi dalam penelitian ini adalah Wajib Pajak Orang Pribadi (Non Karyawan) yang terdaftar Wajib SPT di KPP Pratama Bandung Bojonagara yang berjumlah 8.073 Wajib Pajak. Dengan menggunakan rumus slovin, maka diperoleh sampel dalam penelitian ini adalah Wajib Pajak Orang Pribadi (Non Karyawan) yang melakukan kegiatan usaha atau pekerjaan bebas di KPP Pratama Bandung Bojonagara yang berjumlah 100 orang. Teknik sampel yang digunakan adalah convenience sampling. Data yang digunakan dalam penelitian ini adalah data primer yang didapatkan dari penyebaran kuesioner kepada responden. Teknik analisis yang digunakan dalam penelitian ini adalah teknik analisis statistik deskriptif dan analisis regresi linier berganda.

\section{HASIL}

Pengetahuan Perpajakan didapatkan jumlah skor total dari setiap pernyataan pada kuesioner sebesar 3994 atau sebesar 79,88\% dari total skor ideal atau nilai indeks maksimum. Sehingga dapat disimpulkan bahwa pengetahuan perpajakan yang dimiliki Wajib Pajak Orang Pribadi (Non Karyawan) di KPP Pratama Bandung Bojonagara tergolong baik karena memiliki nilai persentase diantara $68 \%-84 \%$. Pengetahuan perpajakan yang baik yang dimiliki oleh Wajib Pajak Orang Pribadi (Non Karyawan) di KPP Pratama Bandung Bojonagara tergambar melalui jawaban-jawaban responden yang secara keseluruhan setuju dengan pernyataanpernyataan pada kuesioner. Berdasarkan hasil kuesioner dapat dilihat bahwa responden secara keseluruhan telah mengetahui kewajiban dan hak-haknya sebagai Wajib Pajak, telah mengetahui berapa besar tarif pajak yang dikenakan, mengetahui persyaratan timbul dan hapusnya utang pajak, dan sebagainya.

Sosialisasi Perpajakan didapatkan jumlah skor total dari setiap pernyataan pada kuesioner sebesar 3699 atau sebesar $73,98 \%$ dari total skor ideal atau nilai indeks maksimum. Sehingga dapat disimpulkan bahwa sosialisasi perpajakan di KPP Pratama Bandung Bojonagara tergolong baik karena memiliki nilai persentase diantara $68 \%-84 \%$. Sosialisasi perpajakan yang baik di KPP Pratama Bandung Bojonagara tergambar melalui jawaban-jawaban responden yang secara keseluruhan setuju dengan pernyataanpernyataan pada kuesioner. Berdasarkan hasil kuesioner dapat dilihat bahwa sebagian besar responden telah mengetahui adanya sosialisasi perpajakan baik secara langsung maupun tidak langsung dan mereka mengikuti sosialisasi serta memperoleh informasi perpajakan melalui sosialisasi tersebut yang dapat membuat responden atau Wajib Pajak menjadi paham mengenai aspek teknis perpajakan dan menjadi peduli serta sadar akan pentingnya pajak bagi negara dan masyarakat.

Pelayanan Fiskus didapatkan jumlah skor total dari setiap pernyataan pada kuesioner sebesar 5396 
atau sebesar $83 \%$ dari total skor ideal atau nilai indeks maksimum. Sehingga dapat disimpulkan bahwa pelayanan fiskus di KPP Pratama Bandung Bojonagara tergolong baik karena memiliki nilai persentase diantara 68\%-84\%. Pelayanan fiskus yang baik di KPP Pratama Bandung Bojonagara tergambar melalui jawabanjawaban responden yang secara keseluruhan setuju bahkan sangat setuju dengan pernyataan-pernyataan pada kuesioner. Berdasarkan hasil kuesioner dapat dilihat bahwa pegawai atau petugas pajak (fiskus) yang melayani langsung Wajib Pajak menjaga sopan santun dan perilaku, ramah (memberikan sapa, senyum, dan salam), tanggap, cermat dan cepat, serta tidak mempersulit pelayanan. Selain itu Wajib Pajak juga mendapatkan pelayanan dari petugas pajak (fiskus) mulai dari pukul 08.00 sampai dengan 16.00 waktu setempat, petugas pajak (fiskus) baik petugas konseling (helpdesk) atau Account Representative (AR) siaga dalam melayani pertanyaan Wajib Pajak, dan sebagainya.

Kepatuhan Wajib Pajak didapatkan jumlah skor total dari setiap pernyataan pada kuesioner sebesar 4486 atau sebesar 81,56\% dari total skor ideal atau nilai indeks maksimum. Sehingga dapat disimpulkan bahwa Kepatuhan Wajib Pajak untuk Wajib Pajak Orang Pribadi (Non Karyawan) di KPP Pratama Bandung Bojonagara tergolong baik karena memiliki nilai persentase diantara 68\%-84\%. Kepatuhan Wajib Pajak yang baik di KPP Pratama Bandung Bojonagara tergambar melalui jawaban-jawaban responden yang secara keseluruhan setuju bahkan sangat setuju dengan pernyataan-pernyataan pada kuesioner. Berdasarkan hasil kuesioner dapat dilihat bahwa responden atau Wajib Pajak secara keseluruhan telah melaksnakan kewajiban perpajakannya dengan baik dimana Wajib Pajak telah mendaftarkan diri pada KPP Pratama Bandung Bojonagara untuk mendapatkan Nomor Pokok Wajib Pajak (NPWP), mengisi Surat Pemberitahuan (SPT) dengan benar, lengkap, dan jelas, serta menyampaikannya ke KPP Pratama Bandung Bojonagara, melakukan pembayaran dan penyetoran pajak terutang tepat waktu atau sebelum jatuh tempo, menyampaikan Surat Pemberitahuan (SPT) ke KPP Pratama Bandung Bojonagara sebelum batas waktu, dan sebagainya.

Berdasarkan pengujian validitas bahwa setiap pernyataan pada kuesioner untuk variabel pengetahuan perpajakan, sosialisasi perpajakan, dan pelayanan fiskus memiliki nilai $r$ hitung lebih besar atau di atas 0,1946 ( $\mathrm{r}$ hitung $>\mathrm{r}$ tabel) sehingga dapat dikatakan bahwa setiap pernyataan pada kuesioner untuk setiap variabel adalah valid dan layak digunakan.

Berdasarkan pengujian reliabilitas untuk variabel pengetahuan perpajakan, sosialisasi perpajakan, pelayanan fiskus, dan kepatuhan Wajib Pajak masingmasing adalah sebesar 0,761, 0,768, 0,758, dan 0,753. Sehingga dapat disimpulkan bahwa pernyataan kuesioner pada setiap variabel adalah reliabel atau handal karena memiliki nilai Cronbach Alpha $(\alpha)$ lebih besar dari 0,70 (>0,70).

Berdasarkan hasil uji normalitas dengan uji statistik non-parametrik Kolmogorov-Smirnov didapatkan nilai Asymp. Sig. lebih besar dari $0.05(>0,05)$ yaitu sebesar 0,200 yang artinya adalah data residual berdistirbusi normal.

Berdasarkan hasil uji multikolinieritas didapatkan nilai tolerance untuk ketiga variabel bebas yaitu pengetahuan pepajakan, sosialisasi perpajakan, dan pelayanan fiskus adalah masing-masing sebesar 0,780, 0,638, dan 0,716 sedangkan untuk nilai VIF, ketiga variabel bebas tersebut memiliki nilai VIF masingmasing sebesar 1,282, 1,568, dan 1,397. Ketiga variabel bebas tersebut memiliki nilai tolerance lebih besar dari $0,10(>0,10)$ dan memiliki nilai VIF lebih kecil dari $10(<10)$, sehingga dapat disimpulkan bahwa tidak terdapat multikolinieritas di dalam model regresi atau tidak terdapat korelasi antar variabel bebas di dalam model regresi.

Berdasarkan hasil uji heteroskedastisitas dengan melihat grafik plot didapatkan bahwa tidak terdapat pola yang jelas, serta titik-titik menyebar diatas dan dibawah angka 0 pada sumbu Y, maka dapat disimpulkan bahwa pada model regresi tidak terjadi heteroskedastisitas.

Tabel 2. Hasil Analisis Regresi Linier Berganda Coefficients $^{\mathrm{a}}$

\begin{tabular}{|c|c|c|c|c|c|c|}
\hline & & \multicolumn{2}{|c|}{$\begin{array}{c}\text { Unstandardized } \\
\text { Coefficients }\end{array}$} & $\begin{array}{l}\text { Standardized } \\
\text { Coefficients }\end{array}$ & \multirow[b]{2}{*}{$\mathrm{t}$} & \multirow[b]{2}{*}{ Sig. } \\
\hline \multicolumn{2}{|c|}{ Model } & B & $\begin{array}{l}\text { Std. } \\
\text { Error }\end{array}$ & Beta & & \\
\hline \multirow[t]{4}{*}{1} & (Constant) & ,646 &, 311 & & 2,075 &, 041 \\
\hline & $\begin{array}{l}\text { Pengetahuan } \\
\text { Perpajakan }\end{array}$ & ,366 & ,082 &, 379 & 4,437 &, 000 \\
\hline & $\begin{array}{l}\text { Sosialisasi } \\
\text { Perpajakan }\end{array}$ & ,090 & ,087 & ,098 & 1,042 & ,300 \\
\hline & $\begin{array}{l}\text { Pelayanan } \\
\text { Fiskus }\end{array}$ &, 350 & ,085 &, 367 & 4,116 &, 000 \\
\hline
\end{tabular}

a. Dependent Variable: Kepatuhan Wajib Pajak

Sumber: Data Primer yang telah diolah penulis dengan SPSS 22 (2017)

Berdasarkan pengujian yang telah dilakukan didapatkan nilai konstanta sebesar 0,646 dan koefisien regresi sebesar $0,366(\beta 1), 0,90(\beta 2)$, dan $0,350(\beta 3)$ sehingga terbentuk persamaan linier berganda sebagai berikut:

$$
\mathrm{Y}=0,646+0,366 \mathrm{X}_{1}+0,90 \mathrm{X}_{2}+0,350 \mathrm{X}_{3}+\mathrm{e}
$$

Persamaan regresi linier berganda tersebut dapat dijelaskan bahwa nilai konstanta sebesar 0,646, nilai koefisien regresi variabel Pengetahuan Perpajakan bernilai positif 0,366 menunjukkan bahwa semakin tinggi atau baik Pengetahuan Perpajakan yang dimiliki 
maka semakin baik pula Kepatuhan Wajib Pajak.

Nilai koefisien regresi variabel Sosialisasi Perpajakan bernilai positif 0,90 menunjukkan bahwa semakin tinggi atau baik Sosialisasi Perpajakan maka semakin baik pula Kepatuhan Wajib Pajak. Nilai koefisien regresi variabel Pelayanan Fiksus bernilai positif 0,350 menunjukkan bahwa semakin tinggi atau baik Pelayanan Fiskus maka semakin baik pula Kepatuhan Wajib Pajak.

Tabel 3. Hasil Uji Statistik F ANOVA $^{\mathrm{a}}$

\begin{tabular}{llccccc}
\hline & & Sum of & \multicolumn{3}{c}{ Mean } & \\
\multicolumn{1}{l}{ Model } & & Squares & df & Square & F & Sig. \\
\hline 1 & Regression & 15,291 & 3 & 5,097 & 26,476 &, $000^{\mathrm{b}}$ \\
& Residual & 18,482 & 96 &, 193 & & \\
& Total & 33,773 & 99 & & & \\
\hline
\end{tabular}

Sumber: Data Primer yang telah diolah penulis dengan SPSS 22 (2017)

Berdasarkan hasil uji statistik $\mathrm{F}$ didapat nilai signifikansi sebesar 0,000 artinya Pengetahuan Perpajakan, Sosialisasi Perpajakan, dan Pelayanan Fiskus secara simultan berpengaruh signifikan terhadap kepatuhan Wajib Pajak Orang Pribadi (Non Karyawan) (Y) di KPP Pratama Bandung Bojonagara.

Tabel 4. Hasil Koefisien Determinasi $\left(\mathrm{R}^{2}\right)$ Model Summary ${ }^{\mathrm{b}}$

\begin{tabular}{ccccc}
\hline Model & $\mathrm{R}$ & R Square & $\begin{array}{c}\text { Adjusted R } \\
\text { Square }\end{array}$ & $\begin{array}{c}\text { Std. Error of } \\
\text { the Estimate }\end{array}$ \\
\hline 1 &, $673^{\mathrm{a}}$ &, 453 &, 436 &, 43877 \\
\hline \multicolumn{2}{l}{ Sumber: Data Primer yang telah diolah penulis dengan SPSS 22(2017) }
\end{tabular}

Pada Tabel 4 didapatkan nilai Adjusted R Square adalah sebesar 0,436 atau $43,6 \%$. Hal tersebut menggambarkan bahwa Pengetahuan Perpajakan, Sosialisasi Perpajakan, dan Pelayanan Fiskus mempengaruhi Kepatuhan Wajib Pajak sebesar 43,6\% sedangkan sisanya sebesar $56,4 \%$ dipengaruhi oleh variabel lain yang tidak terdapat di dalam penelitian ini.

Tabel 5. Hasil Uji Statistik t Coefficients $^{\mathrm{a}}$

\begin{tabular}{|c|c|c|c|c|c|c|}
\hline \multirow[b]{2}{*}{ Mode } & & \multicolumn{2}{|c|}{$\begin{array}{c}\text { Unstandardized } \\
\text { Coefficients }\end{array}$} & $\begin{array}{l}\text { Standardized } \\
\text { Coefficients }\end{array}$ & \multirow[b]{2}{*}{$\mathrm{t}$} & \multirow[b]{2}{*}{ Sig. } \\
\hline & & B & $\begin{array}{l}\text { Std. } \\
\text { Error }\end{array}$ & Beta & & \\
\hline \multirow[t]{4}{*}{1} & (Constant) & ,646 &, 311 & & 2,075 &, 041 \\
\hline & $\begin{array}{l}\text { Pengetahuan } \\
\text { Perpajakan }\end{array}$ & ,366 &, 082 & ,379 & 4,437 &, 000 \\
\hline & $\begin{array}{l}\text { Sosialisasi } \\
\text { Perpajakan }\end{array}$ & ,090 &, 087 & ,098 & 1,042 & ,300 \\
\hline & $\begin{array}{l}\text { Pelayanan } \\
\text { Fiskus }\end{array}$ & ,350 &, 085 & ,367 & 4,116 &, 000 \\
\hline
\end{tabular}

Sumber: Data Primer yang telah diolah penulis dengan SPSS 22 (2017)
Berdasarkan Tabel 5 dapat dilihat bahwa Pengetahuan Perpajakan memiliki nilai signifikansi sebesar 0,000 sehingga dapat disimpulkan bahwa Pengetahuan Perpajakan secara parsial berpengaruh signifikan dengan arah yang positif terhadap Kepatuhan Wajib Pajak Orang Pribadi (Non Karyawan) di KPP Pratama Bandung Bojonagara.

Sosialisasi Perpajakan memiliki nilai signifikansi sebesar 0,300 sehingga dapat disimpulkan bahwa Sosialisasi Perpajakan secara parsial tidak berpengaruh signifikan terhadap Kepatuhan Wajib Pajak Orang Pribadi (Non Karyawan) di KPP Pratama Bandung Bojonagara.

Pelayanan Fiskus memiliki nilai signifikansi sebesar 0,000 sehingga dapat disimpulkan bahwa Pelayanan Fiskus secara parsial berpengaruh signifikan dengan arah yang positif terhadap Kepatuhan Wajib Pajak Orang Pribadi (Non Karyawan) di KPP Pratama Bandung Bojonagara.

\section{PEMBAHASAN}

Berdasarkan hasil pengujian secara parsial (Uji Statistik t), untuk variabel Pengetahuan Perpajakan didapatkan nilai signifikansi sebesar 0,000 dimana nilai tersebut lebih kecil dari $0,05(<0,05)$ dan didapatkan nilai koefisien regresi sebesar 0,366 , sehingga dapat disimpulkan bahwa $\mathrm{H} 0$ ditolak dan Ha diterima yang artinya Pengetahuan Perpajakan secara parsial berpengaruh signifikan dengan arah yang positif terhadap Kepatuhan Wajib Pajak Orang Pribadi (Non Karyawan) di KPP Pratama Bandung Bojonagara. Hal tersebut menunjukkan bahwa semakin tinggi atau baik Pengetahuan Perpajakan yang dimiliki maka semakin baik pula Kepatuhan Wajib Pajak Orang Pribadi (Non Karyawan) di KPP Pratama Bandung Bojonagara. Berdasarkan hasil kuesioner yang telah dianalisis dengan statistik deskriptif dan digambarkan dengan garis kontinum, tergambar bahwa untuk variabel pengetahuan perpajakan didapatkan persentase jumlah skor total atas jawaban responden terhadap kuesioner sebesar 79,88\%, yang artinya pengetahuan perpajakan yang dimiliki oleh Wajib Pajak Orang Pribadi (Non Karyawan) di KPP Pratama Bandung Bojonagara tergolong baik. Hal tersebut dapat terlihat dari Wajib Pajak Orang Pribadi (Non Karyawan) di KPP Pratama Bandung Bojonagara yang sebagian besar telah mengetahui kewajiban dan hak-haknya sebagai Wajib Pajak, mengetahui berapa besar tarif pajak yang dikenanakan, mengetahui syarat timbul dan hapusnya utang pajak, dan sebagainya.

Dengan Wajib Pajak mengetahui dan memahami seluruh ketentuan terkait dengan kewajiban perpajakan yang berlaku maka Wajib Pajak akan dengan mudah melaksanakan kewajiban perpajakannya (Zuhdi, et al, 2015), dengan kata lain dengan tingkat pengetahuan perpajakan yang baik dan memadai yang dimiliki oleh masyarakat khususnya Wajib Pajak, maka akan mudah 
bagi Wajib Pajak untuk patuh pada peraturan perpajakan (Rahayu, 2010:29).

Hasil penelitian ini sejalan dengan penelitian yang dilakukan Zuhdi, et al (2015) yang menyatakan bahwa pengetahuan perpajakan berpengaruh terhadap kepatuhan Wajib Pajak dan penelitian yang dilakukan oleh Murti, et al (2014) yang menyatakan bahwa pengetahuan perpajakan berpengaruh secara signifikan terhadap kepatuhan Wajib Pajak Orang Pribadi.

Berdasarkan hasil pengujian secara parsial (Uji Statistik t), untuk variabel Sosialisasi Perpajakan didapatkan nilai signifikansi sebesar 0,300 dimana nilai tersebut lebih besar dari $0,05(>0,05)$ dan didapatkan nilai koefisien regresi sebesar 0,90 , sehingga dapat disimpulkan bahwa H0 diterima dan Ha ditolak yang artinya Sosialisasi Perpajakan secara parsial tidak berpengaruh signifikan terhadap Kepatuhan Wajib Pajak Orang Pribadi (Non Karyawan) di KPP Pratama Bandung Bojonagara. Hal tersebut menunjukkan semakin tinggi atau baik Sosialisasi Perpajakan di KPP Pratama Bandung Bojonagara maka tidak mempengaruhi Kepatuhan Wajib Pajak Orang Pribadi (Non Karyawan) di KPP Pratama Bandung Bojonagara. Berdasarkan hasil kuesioner yang telah dianalisis dengan statistik deskriptif dan digambarkan dengan garis kontinum, tergambar bahwa untuk variabel sosialisasi perpajakan didapatkan persentase jumlah skor total atas jawaban responden terhadap kuesioner sebesar 73,98\%, yang artinya sosialisasi perpajakan di KPP Pratama Bandung Bojonagara tergolong baik. Hal tersebut dapat terlihat dari Wajib Pajak Orang Pribadi (Non Karyawan) di KPP Pratama Bandung Bojonagara yang sebagian besar telah mengetahui adanya sosialisasi perpajakan baik secara langsung maupun tidak langsung dan mengikuti sosialisasi serta memperoleh informasi perpajakan melalui sosialisasi tersebut. Namun, sosialisasi perpajakan yang baik belum tentu dapat mempengaruhi kepatuhan Wajib Pajak Orang Pribadi (Non Karyawan) di KPP Pratama Bandung Bojonagara. Hal tersebut disebabkan karena Wajib Pajak tidak dapat memahami dengan baik materi atau informasi perpajakan yang disampaikan oleh KPP dan karena materi atau informasi perpajakan tidak bersifat detail. Ketidakpahaman responden atau Wajib Pajak terhadap materi atau informasi perpajakan yang disampaikan dapat disebabkan karena jumlah Wajib Pajak yang mengikuti sosialisasi langsung tersebut cukup banyak sehingga materi atau informasi perpajakan yang disampaikan tidak dapat tersampaikan dengan baik secara menyeluruh kepada para Wajib Pajak dengan kata lain sosialisasi tersebut tidak berjalan dengan efektif. Untuk sosialisasi tidak langsung, dapat disebabkan karena kegiatan sosialisasi tidak langsung relatif singkat serta materi dan informasi perpajakan yang disampaikan cenderung bersifat umum (tidak detail) dan mungkin saja media yang digunakan tidak sesuai dengan kajian atau kurang tepat untuk audience.
Hasil penelitian ini sejalan dengan penelitian yang dilakukan oleh Yuliasari, et al (2015) yang menyatakan bahwa sosialisasi perpajakan tidak berpengaruh secara signifikan terhadap kepatuhan Wajib Pajak Orang Pribadi dan penelitian yang dilakukan oleh Winerungan (2013) yang menyatakan bahwa sosialisasi perpajakan tidak berpengaruh terhadap kepatuhan Wajib Pajak Orang Pribadi.

Berdasarkan hasil pengujian secara parsial (Uji Statistik t), untuk variabel Pelayanan Fiskus didapatkan nilai signifikansi sebesar 0,000 dimana nilai tersebut lebih kecil dari 0,05 $(<0,05)$ dan didapatkan nilai koefisien regresi sebesar 0,350 , sehingga dapat disimpulkan bahwa H0 ditolak dan Ha diterima yang artinya Pelayanan Fiskus secara parsial berpengaruh signifikan dengan arah yang positif terhadap Kepatuhan Wajib Pajak Orang Pribadi (Non Karyawan) di KPP Pratama Bandung Bojonagara. Hal tersebut menunjukkan bahwa semakin tinggi atau baik Pelayanan Fiskus di KPP Pratama Bandung Bojonagara maka semakin baik pula Kepatuhan Wajib Pajak Orang Pribadi (Non Karyawan) di KPP Pratama Bandung Bojonagara. Berdasarkan hasil kuesioner yang telah dianalisis dengan statistik deskriptif dan digambarkan dengan garis kontinum, tergambar bahwa untuk variabel pelayanan fiskus didapatkan persentase jumlah skor total atas jawaban responden terhadap kuesioner sebesar 83\%, yang artinya pelayanan fiskus di KPP Pratama Bandung Bojonagara tergolong baik. Hal tersebut dapat terlihat dari Wajib Pajak Orang Pribadi (Non Karyawan) di KPP Pratama Bandung Bojonagara yang sebagian besar setuju bahwa pegawai atau petugas pajak (fiskus) yang melayani langsung Wajib Pajak menjaga sopan santun dan perilaku, ramah (memberikan sapa, senyum, dan salam), tanggap, cermat dan cepat, serta tidak mempersulit pelayanan. Selain itu Wajib Pajak juga mendapatkan pelayanan dari petugas pajak (fiskus) mulai dari pukul 08.00 sampai dengan 16.00 waktu setempat, petugas pajak (fiskus) baik petugas konseling (helpdesk) atau Account Representative (AR) siaga dalam melayani pertanyaan Wajib Pajak, dan sebagainya.

Pelayanan yang diberikan oleh fiskus selama proses perpajakan berkaitan dengan sikap Wajib Pajak dalam melaksanakan kewajiban perpajakannya. Wajib Pajak secara konsisten akan meningkatkan kepatuhan bila terdapat pelayanan yang baik oleh aparat perpajakan (Yuliasari, et al 2015). Dengan kata lain dengan adanya pelayanan bersifat prima atau pelayanan yang baik yang diberikan oleh fiskus kepada Wajib Pajak dapat mencapai tingkat kepatuhan Wajib Pajak yang tinggi, dalam kondisi Wajib Pajak merasa puas atas pelayanan yang diberikan oleh fiskus maka Wajib Pajak cenderung akan melaksanakan kewajiban perpajakannya sesuai dengan ketentuan yang berlaku (Rahayu, 2010:28).

Hasil penelitian ini sejalan dengan penelitian yang dilakukan Yuliasari, et al (2015) yang menyatakan bahwa pelayanan fiskus berpengaruh secara signifikan 
terhadap kepatuhan Wajib Pajak. Begitu pula dengan penelitian yang dilakukan oleh Murti, et al (2014) yang menyatakan bahwa pelayanan fiskus berpengaruh secara signifikan terhadap kepatuhan Wajib Pajak Orang Pribadi. Penelitian yang dilakukan oleh Dharma dan Suardana (2014) juga menyatakan bahwa kualitas pelayanan berpengaruh secara signifikan terhadap kepatuhan Wajib Pajak dalam membayar pajak.

\section{KESIMPULAN}

Secara deskriptif dapat disimpulkan bahwa pengetahuan perpajakan Wajib Pajak Orang Pribadi (Non karyawan), sosialisasi perpajakan, pelayanan fiskus, dan kepatuhan Wajib Pajak Orang Pribadi (Non Karyawan) di KPP Pratama Bandung Bojonagara tergolong baik. Hal tersebut terlihat dari Wajib Pajak yang secara keseluruhan telah mengetahui kewajiban dan hak-haknya sebagai Wajib Pajak, mengetahui berapa besar tarif pajak yang dikenakan, mengetahui syarat timbul dan hapusnya utang pajak, dan sebagainya. Sebagian besar Wajib Pajak juga telah mengetahui adanya sosialisasi perpajakan baik secara langsung maupun tidak langsung yang dilakukan oleh KPP Pratama Bandung Bojonagara dan Wajib Pajak mengikuti sosialisasi serta memperoleh informasi perpajakan melalui sosialisasi tersebut. Pelayanan yang baik di KPP Pratama Bandung Bojonagara terlihat dari pegawai atau petugas pajak (fiskus) di KPP yang menjaga sopan santun dan perilaku, ramah (memberikan sapa, senyum, dan salam), tanggap, cermat dan cepat, serta tidak mempersulit pelayanan dalam melayani langsung Wajib Pajak, selain itu petugas pajak (fiskus) baik petugas konseling (helpdesk) atau Account Representative (AR) juga siaga dalam melayani pertanyaan Wajib Pajak, dan sebagainya. Wajib Pajak Orang Pribadi (Non Karyawan) di KPP Pratama Bandung Bojonagara secara keseluruhan telah patuh dalam menjalankan kewajiban perpajakannya seperti, Wajib Pajak telah mendaftarkan diri pada KPP Pratama Bandung Bojonagara untuk mendapatkan Nomor Pokok Wajib Pajak (NPWP), Wajib Pajak mengisi Surat Pemberitahuan (SPT) dengan benar, lengkap, dan jelas, serta menyampaikannya ke KPP Pratama Bandung Bojonagara, melakukan pembayaran dan penyetoran pajak terutang tepat waktu atau sebelum jatuh tempo, menyampaikan Surat Pemberitahuan (SPT) ke KPP Pratama Bandung Bojonagara sebelum batas waktu, dan sebagainya.

Berdasarkan pengujian hipotesis secara simultan, diperoleh bahwa pengetahuan perpajakan, sosialisasi perpajakan, dan pelayanan fiskus berpengaruh signifikan terhadap kepatuhan Wajib Pajak Orang Pribadi (Non Karyawan) di KPP Pratama Bandung Bojonagara. Untuk pengujian hipotesis secara parsial, diperoleh bahwa pengetahuan perpajakan dan pelayanan fiskus secara parsial berpengaruh signifikan dengan arah yang positif terhadap kepatuhan Wajib Pajak Orang Pribadi (Non Karyawan) di KPP Pratama Bandung Bojonagara sedangkan sosialisasi perpajakan secara parsial tidak berpengaruh signifikan terhadap kepatuhan Wajib Pajak Orang Pribadi (Non Karyawan) di KPP Pratama Bandung Bojonagara.

\section{DAFTAR PUSTAKA}

Andinata, M.C., 2014. Analisis Faktor-Faktor yang Mempengaruhi Kepatuhan Wajib Pajak Orang Pribadi dalam Membayar Pajak: Studi Kasus Pada Kantor Pelayanan Pajak Pratama surabaya Rungkut di Surabaya.

Andreas dan Savitri, Enni. 2015. The Effect of Tax Socialization, Tax Knowledge, Expediency of Tax ID Number and Service Quality on Taxpayers Compliance With Taxpayers Awareness as Mediating Variables. Procedia - Social and Behavioral Sciences 211 (2015) 163 - 169; 2nd Global Conference on Business and Social Science-2015, GCBSS-2015.

Dharma, Gede Pani Esa dan Suardana, Ketut Alit. 2014. Pengaruh Kesadaran Wajib Pajak, Sosialisasi Perpajakan, Kualitas Pelayanan pada Kepatuhan Wajib Pajak. E-Jurnal Akuntansi Universitas Udayana 6.1; 2014; Hal. 340-353; ISSN 2302-8556.

Direktorat Jenderal Pajak Kementerian Keuangan. 2012, 4 Juli. Strategi Meningkatkan Kepatuhan Wajib Pajak [online].

Direktorat Jenderal Pajak Kementerian Keuangan. 2016, 23 Maret. Refleksi Tingkat Kepatuhan Wajib Pajak [online].

Kementerian Keuangan Republik Indonesia. 2016, 4 Maret. Menkeu: Tax Ratio Indonesia di Bawah Standar [online].

Mardiasmo. 2016. Perpajakan Edisi Terbaru 2016. Yogyakarta: Andi Offset.

Murti, Hangga Wicaksono, et al. 2014. Pelayanan Fiskus dan Pengetahuan Perpajakan Terhadap Kepatuhan Wajib Pajak Orang Pribadi Di Kota Manado. Jurnal EMBA; Vol.2 No. 3; September 2014; Hal. 389398; ISSN 2303-1174.

Oladipupo, Adesina Olugoke dan Obazee, Uyioghosa. 2016. Tax Knowledge, Penalties and Tax Compliance in Small and Medium Scale Enterprises in Nigeria. iBusiness, Vol.08 No.01 (2016), Article ID: 64130, 9 pages.

Ortax. 2011. Surat Edaran Direktur Jenderal Pajak Nomor SE-84/PJ/2011 tentang Pelayanan Prima [online].

Ortax. 2011. Surat Edaran Direktur Jenderal Pajak Nomor: SE-98/PJ/2011 Tentang Pedoman Penyusunan Rencana Kerja dan Laporan Kegiatan Penyuluhan Perpajakan Unit Vertikal di Lingkungan Direktorat Jenderal Pajak [online].

Palil, Mohd Rizal, et al. 2013. The Perception of Tax Payers on Tax Knowledge and Tax Education with 
level of tax compliance: A Study the Influences of Religiosity. ASEAN Journal of Economics; Management and Accounting 1 (1); 118-129 (June 2013); ISSN 2338-9710.

Pratiwi, Lena. 2012 .Analisis Pengaruh Pengetahuan Pajak, Kesadaran Dan Niat, Dan Persepsi Tentang Sanksi Pajak Terhadap Kepatuhan Wajib Pajak orang Pribadi Di Purwokerto [online].

PRLM. 2013. 18 Desember. Kesadaran Masyarakat Bayar Pajak Minim [online].

Rahayu, Siti Kurnia. 2010. Perpajakan Indonesia Konsep \& Aspek Formal. Yogyakarta: Graha Ilmu.

Republik Indonesia. 2009. Undang-undang Nomor 16 Tahun 2009 tentang Perubahan Ke-empat atas Undang-undang Nomor 6 Tahun 1983 tentang Ketentuan Umum dan Tata Cara Perpajakan. Jakarta.

Saad, Natrah. 2014. Tax Knowledge, Tax Complexity and Tax Compliance: Taxpayers'View. Procedia - Social and Behavioral Sciences 109 (2014) 1069-1075; 2nd World Conference on Business, Economics and Management-WCBEM 2013.

Savitri, Enni dan Musfialdy. 2016. The Effect of Taxpayer Awareness, Tax Socialization, Tax Pinalties, Compliance Cost at Taxpayer Compliance with
Service Quality as Mediating Variable. Procedia - Social and Behavioral Sciences 219 (2016) 682687; 3rd Global Conference on Business and Social Science-2015, GCBSS-2015.

Simanjuntak, Timbul H, dan Mukhlis, Imam. 2012. Dimensi Ekonomi Perpajakan Dalam Pembangunan Ekonomi. Jakarta: Raih Asa Sukses.

Winerungan, Oktaviane Lidya. 2013. Sosialisasi Perpajakan, Pelayanan Fiskus, dan Sanksi Perpajakan Terhadap Kepatuhan WPOP Di KPP Manado dan KPP Bitung. Jurnal EMBA; Vol.1 No.3; September 2013; Hal. 960-970; ISSN 23031174.

Yuliasari, Wirda Salisa, et al. 2015. Pengaruh Sosialisasi Perpajakan, Pelayanan Fiskus, dan Sanksi Terhadap Kepatuhan Wajib Pajak Orang Pribadi (Studi pada Wajib Pajak Orang Pribadi di KPP Pratama Ponorogo). Jurnal Administrasi Bisnis - Perpajakan (JAB); Vol. 4 No. 2.

Zuhdi, Firdaus Aprian, et al. 2015. Pengaruh Penerapan E-SPT dan Pengetahuan Perpajakan Terhadap Kepatuhan Wajib Pajak (Studi Pada Pengusaha Kena Pajak yang terdaftar di KPP Pratama Singosari). Jurnal Perpajakan (JEJAK); Vol. 7 No.1. 